\title{
Organic Matter Turnover in Light Fraction and Whole Soil Under Silvopastoral Land Use in Semiarid Northeast Brazil
}

\author{
Barbara Wick ${ }^{1}$ and Holm Tiessen ${ }^{2}$ \\ Authors are ${ }^{1}$ Research Associate, Humboldt University Berlin, Department of Soil Science and Site Science, 10115 Berlin, Germany; and ${ }^{2}$ Professor and \\ Director, Inter-American Institute for Global Change Research (IAI), São José dos Campos, SP 12227-010, Brazil.
}

\begin{abstract}
Trees in silvopastoral systems can accumulate carbon (C) and nutrients under their canopies. Most studies measure only net changes in organic matter and nutrients without evaluating turnover of soil organic matter. Here, the change in vegetation cover from caatinga, a semideciduous thorn forest (principally $\mathrm{C}_{3}$ metabolism) to buffel grass (Cenchrus ciliaris $\mathrm{L}$.) pasture ( $\mathrm{C}_{4}$ metabolism) was used to quantify in situ input and turnover rates of organic carbon $14 \mathrm{yr}$ after land-use changes. The accretion of $\mathrm{C}$ under new pasture and loss of original caatinga $\mathrm{C}$ was studied for whole soil (WS) and light fraction (LF). The effects of two tree species preserved during selective clearing and one species planted after complete clearing of caatinga were evaluated. All trees prevented organic matter mineralization that occurred in surrounding cleared pasture. The $\mathrm{C}$ mineralization under pasture was twice as high (66\% loss) in LF as in WS $\left(34 \%\right.$ loss) over $14 \mathrm{yr}$. The $\mathrm{C}_{4}-\mathrm{C}$ was similar under and outside the remnant and planted tree canopies, i.e., the input of new $\mathrm{C}_{4}-\mathrm{C}$ did not compensate for the loss of old $\mathrm{C}_{3}-\mathrm{C}$ that occurred following caatinga clearing and pasture establishment. The organic matter in this tropical, semiarid region mineralized rapidly with $\mathrm{C}$ half lives between 9 and $16 \mathrm{yr}$ for LF and between 11 and $28 \mathrm{yr}$ for WS. The ${ }^{13} \mathrm{C}$ data indicate that elevated C contents under preserved (WS and LF) and planted (LF) trees, relative to the pasture outside the tree canopies, largely represent $\mathrm{C}_{3}-\mathrm{C}$ inherited from the caatinga. In this silvopastoral system, derived from land-use changes from dry forest, the islands of fertility and organic matter under the trees were not built up and represent preserved, rather than new, C inputs.
\end{abstract}

\section{Resumen}

Los árboles en sistemas silvopastoriles pueden acumular carbono $(\mathrm{C})$ y nutrientes debajo de sus doseles. Muchos estudios miden solo cambios netos en la materia orgánica y los nutrientes asociados sin evaluar la transformación actual de la materia orgánica del suelo. En este estudio el cambio en la cobertura vegetativa de la Caatinga, un bosque espinoso semideciduos (principalmente metabolismo $\mathrm{C}_{3}$ ), a una pastura (metabolismo $\mathrm{C}_{4}$ ) de grama buffel (Cenchrus ciliaris L.) fue usado para cuantificar in situ la tasa de entrada y la transformación de carbono orgánico catorce años después del cambio de uso de suelo. El incremento de C debajo de la nueva pastura y la pérdida de carbono original de la Caatinga fueron estudiados para el suelo entero (WS) y la fracción livianas (LF). Los efectos de dos especies de árboles conservados durante la poda selectiva de la Caatinga y unas especies plantadas después de completar la poda de la Caatinga fueron evaluados. Todos los árboles impidieron la mineralización de materia orgánica que ocurrió en los alrededores de la pastura podada. La mineralización de C debajo de la pastura fue dos veces tan alta (66\% pérdida) en el LF que en el WS (34\% pérdida) através de los 14 años. El $\mathrm{C}_{4}-\mathrm{C}$ fue similar debajo y fuera de los doseles de los árboles remanentes y plantados, i.e., la entrada de nuevo $\mathrm{C}_{4}-\mathrm{C}$ no compenso la perdida de viejo $\mathrm{C}_{3}-\mathrm{C}$ que había ocurrido luego de la poda de la Caatinga y el establecimiento de la pastura. La materia orgánica en esta región tropical semiárida se mineralizó muy rápidamente con medias vidas entre los 9 y 16 años para el LF, y entre 11 y 28 años para el WS. Los datos de ${ }^{13} \mathrm{C}$ indica que los contenidos de $\mathrm{C}$ elevados debajo de los árboles preservados (WS y LF) y los árboles plantados

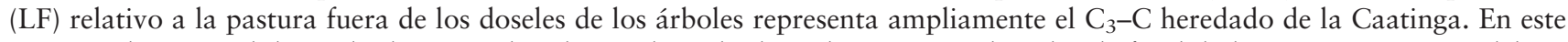
sistema silvopastoril derivado de un cambio de uso de suelo de un bosque seco, las islas de fertilidad y materia orgánica debajo de los árboles no fueron edificaciones nuevas y representan establecimientos preservados más que nuevas entradas de C.

Key Words: agroforestry, caatinga, ${ }^{13} \mathrm{C}$ natural abundance, indigenous trees, islands of fertility, pasture

\section{INTRODUCTION}

Caatinga is the major natural ecosystem of northeast Brazil. Its vegetation cover is spatially discontinuous and has an overstory of drought-deciduous trees or shrubs and an understory of annual herbs and bare patches (Eiten 1992; Sampaio 1995). In

Research was funded by Grant CRN001 from the Inter-American Institute for Global Change Research (|AI).

Correspondence: Dr Barbara Wick, Humboldt University Berlin, Dept of Soil Science and Site Science, 10115 Berlin, Germany. Email: Barbara.Wick@agrar.hu-berlin.de

Manuscript received 20 April 2007; manuscript accepted 4 January 2008. patchy environments, in general, larger amounts of nutrients have been built up under the canopy of individual trees than in the bare interplant areas (Belsky 1994). Trees enrich surface soils by recycling leaf litter that contains nutrients, which may be taken up at depth, or nitrogen, which may be fixed (Young 1997). The positive effects of trees in maintaining soil fertility are employed in the tree fallows of shifting-cultivation systems and in agroforestry or silvopastoral land-use systems that maintain a permanent association between trees and crops or pastures (Rhoades 1997). In silvopastoral systems, soils under tree canopies were reported to have higher concentrations of organic matter, increased microbial activity and nutrient 
availability, and improved microclimatic conditions compared with neighboring grasslands (Weltzin and Coughenour 1990; Garcia-Miragaya et al. 1994; Wick et al. 2000; Menezes et al. 2002; Tiessen et al. 2002). Therefore, isolated trees in grasslands or savannas are associated with "resource islands" or "islands of fertility" (Zinke 1962; Belsky 1994). Traditionally, land-use systems that combine trees with pastures are created by selective cutting of native forest or savanna vegetation; during which, trees that are judged valuable by the land users are left standing. In newer silvopastoral initiatives, selected tree species, often fast-growing legumes with a history of agroforestry use, are planted-sometimes at quite high densities of 100 trees $\cdot \mathrm{ha}^{-1}$.

Nutrient mobilization depends on turnover and mineralization of soil organic matter (SOM). Organic nutrient supply depends on SOM turnover, which can be evaluated by organic matter fractionations. Physical fractionations are widely used research tools in determining the quality and turnover of SOM (Accoe et al. 2002; Liao et al. 2006b). The physical fractionation of SOM is based on the concept that SOM fractions with different densities or that are associated with mineral particles of different sizes vary in structure and turnover because of different degrees of organomineral complexation (Christensen 1992). Differentiation of coarse and fine or mineral-associated fractions is useful because carbon (C) turnover of clay-associated or silt-associated organic matter is slower than that of free, light organic debris (Tiessen and Stewart 1983). Grasslands and forest may contain $3 \%-10 \%$ of its $\mathrm{C}$ in the light fraction (LF; Gregorich and Janzen 1996). The LF is enriched in C, nitrogen (N), and organic phosphorus $\left(\mathrm{P}_{\mathrm{o}}\right)$ relative to fractions dominated by mineral constituents (Curtin et al. 2003). The LF consists of relatively undecomposed plant (including roots) and animal residues, part of the soil microbial biomass, fungal hyphae, seeds, and charcoal not complexed with soil minerals (Gregorich and Janzen 1996). This material is relatively unaltered and of more recent origin than the mineral-associated heavy fraction as indicated by younger ${ }^{14} \mathrm{C}$ ages (Trumbore 1993; Tiessen et al. 1994). Despite its wider C:nutrient ratio, the LF serves as a readily decomposable substrate for the soil microbial biomass and is a short-term reservoir of plant nutrients (Boone 1994; Hassink 1995; Whalen et al. 2000; Compton and Boone 2002). The fraction is more sensitive to management-induced changes than the whole soil (WS; Janzen et al. 1992; Barrios et al. 1996) and has been suggested as an early indicator of the effects of soil management on SOM quantity and quality (Gregorich et al. 1994; Haynes 2000).

Normally, only net changes in organic matter and associated nutrients are distinguished without evaluating actual turnover of SOM from different vegetation sources and in different soil fractions. Natural ${ }^{13} \mathrm{C}$ abundance has been used to estimate the turnover rates of SOM when the original vegetation was replaced by plants with a different photosynthetic pathway because the $\delta^{13} \mathrm{C}$ value of SOM reflects the relative proportion of $\mathrm{C}_{3}$ to $\mathrm{C}_{4}$ plant material present (Balesdent et al. 1987). A change in vegetation type, e.g., from forest with a $\mathrm{C}_{3}$ photosynthetic pathway to pasture with a $\mathrm{C}_{4}$ photosynthetic pathway, results in a change in the $\delta^{13} \mathrm{C}$ of the soil $\mathrm{C}$. From that, it is possible to calculate the proportion of $\mathrm{C}$ remaining from the original vegetation and to follow the incorporation of the new $\mathrm{C}$.

In this study, the change in vegetation cover from caatinga, a semideciduous thorn forest $\left(\mathrm{C}_{3}-\mathrm{C}\right)$ to buffel grass (Cenchrus ciliaris $\mathrm{L}$.) pasture $\left(\mathrm{C}_{4}-\mathrm{C}\right)$ was used to follow in situ input rates and mineralization of organic carbon in different soil fractions $14 \mathrm{yr}$ after the land-use change. We applied the natural abundance of ${ }^{13} \mathrm{C}$ to quantify amounts of $\mathrm{C}$ derived from $\mathrm{C}_{3}$ and $\mathrm{C}_{4}$ sources under preserved caatinga trees, planted tree plantations, and surrounding pasture sites. We specifically wanted to determine the rate of loss of the original caatinga $\mathrm{C}_{3}-\mathrm{C}$ from both the LF and the WS and the turnover of the organic matter.

\section{MATERIAL AND METHODS}

\section{Study Region}

The sampling sites were located in a beef cattle ranch at Custodia, Pernambuco, NE Brazil (lat $8^{\circ} 14^{\prime} \mathrm{S}$, long $37^{\circ} 45^{\prime} \mathrm{W}$ ). The native vegetation was caatinga, a semideciduous thorn forest. The rainfall in the area averages $740 \mathrm{~mm} \cdot \mathrm{yr}^{-1}$, concentrated between January and May, with a nearly rainless period between June and December (Sampaio 1995). Mean annual temperature is $26^{\circ} \mathrm{C}$. The soils at the experimental sites are classified, according to US taxonomy, as Alfisols (Haplustalfs) on the uplands and slopes and as Entisols (Ustorthent; alluvial/colluvial) in the lower part of the landscape, often with $<50$-cm-elevation difference between soil types. Both soil types have an average sand content of $75 \%$. Slopes are between $0 \%$ and $4 \%$. The bulk densities at our sampling sites were similar and ranged between 1.34 and $1.49 \mathrm{Mg} \cdot \mathrm{m}^{-3}$.

\section{Sampling Sites}

Until 1984, the study area was covered with $\geq 50$-yr-old native caatinga. In 1984, 3000 ha were completely cleared with tractors and chains, and buffel grass (a perennial tufted bunchgrass with $\mathrm{C}_{4}$ metabolism native to southern Africa) was planted. Prosopis (Prosopis juliflora Swartz D. C.) was planted in the buffel grass pasture $1 \mathrm{yr}$ later at a spacing of 10 by $10 \mathrm{~m}$. $P$. juliflora is an evergreen, potentially $\mathrm{N}$-fixing tree native to central and northern South America (Babos and Cumana 1992). At the time of sampling, in 1998, the tree plantation was 13 yr old.

On the remaining area of the farm $(>3000 \mathrm{ha})$, the land clearing of 1984 preserved two native caatinga species. Joazeiro (Ziziphus joazeiro Mart.) is a nondeciduous tree used for medicinals, fodder, and fuelwood, with fruits that are edible but not marketable (Noel 1995). Umbuzeiro (Spondias tuberosa Arruda Cam.) is deciduous and produces large quantities of marketable fruits. The wood is used for construction (Machado et al. 1997). The preserved, mature trees occurred randomly with a spacing of about 30 to $40 \mathrm{~m}$ in the 14-yr-old pasture.

Joazeiro (J) occurred exclusively in the lower landscape positions. Umbuzeiro (U) occurred on both upper and lower positions. Prosopis $(\mathrm{P})$ was planted only on upper landscape positions. The soils most likely to be different in this landscape may be those surrounding joazeiros because, in the more arid parts of northeast Brazil, these trees are often associated with 
the lowest landscape positions, which can be covered by alluvial materials from surrounding reliefs (Machado et al. 1997). Average soil chemical and physical characteristics at the different locations showed that the upper landscape positions planted to prosopis and surrounding buffel grass pasture (BP) had the highest soil nutrient status and grass productivity, whereas the other sites were not different from each other (Wick et al 2000; Tiessen et al. 2002). Therefore, the area planted to prosopis and the adjacent undisturbed caatinga area (C4) discussed below were treated separately in the data analysis.

The pastures never received chemical fertilization and were mowed with tractors every $2 \mathrm{yr}$ at the end of the dry season to control invasion by woody species. No fires were used in the management of the pastures. Animal density in the ranch was around 0.2 animal $\cdot \mathrm{ha}^{-1}$. The combination of low animal densities and high tree density within the pastures reduced the potential effects of animal droppings on the input of $\mathrm{C}_{4}$-derived carbon and the formation of fertility islands under the trees.

\section{Soil Sampling and Processing}

We sampled four sites at different parts of the farm. Site 1 was located in the lower part of the landscape. Site 2 was located along the slope in the same area about $500 \mathrm{~m}$ away from site 1 . Sites 3 and 4 were situated on uplands and were about $2 \mathrm{~km}$ and $5 \mathrm{~km}$ away from the first sampling area, respectively.

Top soil $(8 \mathrm{~cm})$ samples were taken in February 1998. A total of eight prosopis $(\mathrm{P})$ trees were chosen randomly in a transect $(100 \mathrm{~m})$ parallel to the edge of an undisturbed C4 site. Paired samples were taken for each tree-one sample from under the canopy and one $5 \mathrm{~m}$ away from the canopy edge in the BP, i.e., halfway between trees in the BP and the C4. Within the $\mathrm{C} 4$ site, eight random samples were also collected beneath tree canopies in a transect $(100 \mathrm{~m})$ parallel to the forest edge, so that spatially paired samples were obtained between the caatinga and the adjacent cleared site.

In the area where the clearing had been selective, eight preserved trees each of $\mathrm{J}$ and $\mathrm{U}$ were randomly chosen and three top soil samples were taken from under the canopy of each of those eight $\mathrm{J}$ and $\mathrm{U}$ trees. The direction and the distance of each sample to the tree bole was selected at random. Corresponding samples paired to each of the under-canopy samples were taken from the buffel grass pasture (BJ, BU) following the same direction away from the bole, $5 \mathrm{~m}$ beyond the canopy edge.

Three undisturbed caatinga sites (C1-C3) were also sampled at each of eight random spots along transects $(100 \mathrm{~m})$ parallel to the forest edge. Paired sampling was then done about $10 \mathrm{~m}$ outside the caatinga in adjacent buffel grass sites (BC1, BC2, BC3).

As a result of this sampling scheme, we obtained samples for pairwise comparisons of each tree species with surrounding buffel, of caatinga with adjacent buffel, and of caatinga with adjacent prosopis. In addition, group comparisons were possible between four caatingas, the three tree species, and five areas of buffel grass.

Soil cores were taken with an 8-cm-diameter auger. Subsamples for the determination of water-floatable organic matter $\mathrm{N}$ and $\mathrm{P}(\mathrm{LF})$ were air-dried and sifted through a 2-mm sieve. Subsamples for total $\mathrm{C}, \mathrm{N}$, and $\mathrm{P}_{\mathrm{o}}$ were ground to $<150 \mu \mathrm{m}$ on a ball mill after air drying.

\section{Soil Analysis}

Total $\mathrm{C}$ and $\mathrm{N}$ and ${ }^{13} \mathrm{C}$ abundance were measured on a continuous-flow isotope ratio mass spectrometer (Europa Scientific, Crewe, United Kingdom). Total $\mathrm{P}$ was analyzed by $\mathrm{H}_{2} \mathrm{O}_{2} / \mathrm{H}_{2} \mathrm{SO}_{4}$ digestion and autoanalysis (Thomas et al. 1967). Available $\mathrm{P}$ was determined by resin extraction, and $\mathrm{P}_{\mathrm{o}}$ was determined by summation of hydroxide and hot concentrated acid-extractable $\mathrm{P}_{\mathrm{o}}$ fractions of a sequential extraction, simplified by omitting the bicarbonate and $0.1 \mathrm{~N} \mathrm{HCl}$ extracts from the method of Tiessen and Moir (1993).

$\mathrm{Ca}, \mathrm{Mg}$, and $\mathrm{K}$ were extracted by unbuffered $1 \mathrm{M} \mathrm{NH}_{4} \mathrm{Cl}$. $\mathrm{Ca}$ and $\mathrm{Mg}$ were analyzed by atomic absorption, and $\mathrm{K}$ was analyzed by emission spectrophotometry; $\mathrm{pH}$ was measured in a 1:10 soil:water suspension.

The coarse organic matter fraction was separated by sonifying a soil:water suspension of $20 \mathrm{~g}$ soil and $150 \mathrm{~mL}$ deionized water for $3 \mathrm{~min}$ at $300 \mathrm{~W}$ output with a Braun-sonic sonifier (B. Braun Biotech, Allentown, PA). During sonification, the suspension was cooled in an ice-water bath. The suspension was passed through a 300 -mesh sieve $(50 \mu \mathrm{m})$ to retain both the sand and the water-floatable light organic matter fraction. The retained fraction was mixed and ground in a mortar after oven-drying at $60^{\circ} \mathrm{C} . \mathrm{P}_{\mathrm{o}}$ in the $\mathrm{LF}$ was determined by the ignition method of Saunders and Williams (1955).

\section{Calculation of Carbon Turnover Rates}

Most SOM mineralization described for field conditions represents the net effect of mineralization of old SOM and inputs from new vegetation, which asymptotically leads to a new equilibrium organic matter content. In our study, we distinguish losses from inputs based on their ${ }^{13} \mathrm{C}$ signatures. Accordingly, the origin of soil organic $\mathrm{C}$ was evaluated based on the $\delta^{13} \mathrm{C}$ values determined for leaf material from buffel grass $(-12.6 \%)$ and on an average value of $-26.6 \%$ for the native $\mathrm{C}_{3}$ plants (Tiessen et al. 2002). The fractions of total soil $\mathrm{C}\left(C_{t}\right)$ derived from $\mathrm{C}_{3}$ plants $(C C 3)$ and from $\mathrm{C}_{4}$ plants $(C C 4)$ were calculated according to Balesdent and Mariotti (1996):

$$
\begin{aligned}
& C_{t}=C C 4+C C 3 \\
& C_{t} \times \delta^{13} C_{t}=\left(C C 4 \times \delta^{13} C C 4\right)+\left(C C 3 \times \delta^{13} C C 3\right) \\
& C C 3=\left(\delta^{13} C_{t}-\delta^{13} C C 4\right) /\left(\delta^{13} C C 3-\delta^{13} C C 4\right) \\
& C C 4=\left(\delta^{13} C_{t}-\delta^{13} C C 3\right) /\left(\delta^{13} C C 4-\delta^{13} C C 3\right)
\end{aligned}
$$

with $\delta^{13} C_{t}$ as the measured $\delta^{13} \mathrm{C}$ value of soil $\mathrm{C}, \delta^{13} \mathrm{CC} 4$ as the measured $\delta^{13} \mathrm{C}$ of the $\mathrm{C}_{4}$ plant (here: buffel grass), and $\delta^{13} \mathrm{CC} 3$ as the measured $\delta^{13} \mathrm{C}$ value of the $\mathrm{C}_{3}$ tree species (umbuzeiro, joazeiro, prosopis, caatinga).

The half life was calculated by dividing the mean residence time by two because we assumed linear decay. We chose to use a linear function for several reasons. The decomposition of SOM is driven by a small portion of the labile component. When the labile $\mathrm{C}$ is depleted, the turnover drops rapidly and eventually slows asymptotically. The $k$ values decrease as decomposition proceeds, primarily because of the initial rapid use of low molecular weight (water soluble) components and the more gradual hydrolysis and oxidation of complex C:N 
fractions (e.g., Paul 1984; Jenkinson et al. 1987; Six and Jastrow 2002; Manzoni and Porporato 2007). The significance of the labile fraction for SOM decomposition under tropical conditions has recently been acknowledged in various studies. Organic $\mathrm{C}$ pools with longer residence times typically comprise the largest reservoirs in most temperate soils and exert the greatest influence on the physicochemical reactivity of soils. In tropical soils, however, resistant $\mathrm{C}$ contributes only a minor part because of differences in the mechanisms of organic-matter cycling and stabilization (e.g., Trumbore 1993; Shang and Tiessen 1998; Shang and Tiessen 2001). Studies showed that the majority of the OC in tropical soil has a residence time of $10 \mathrm{yr}$ or less, with a minor component of very refractory C (Trumbore 1993; Tiessen et al. 1994). Even the most resistant fraction of SOM showed a ${ }^{14} \mathrm{C}$ age of only about $100 \mathrm{yr}$ (Tiessen et al. 1994). Previous investigations from northeast Brazil conducted near our study sites revealed that a large portion of SOM was in the form of coarse, unprocessed plant debris of the sand fraction. A search for resistant fractions in soils of northeast Brazil only yielded fractions that were modern, based on ${ }^{14} \mathrm{C}$ dating (Shang and Tiessen 1998).

Therefore, to account for the absence of resistant fractions exhibiting slow turnover rates and the majority $\mathrm{C}$ present in very labile fractions, which turn over very fast (instantaneously), we used linear kinetics to calculate $C$ turnover in the LF and the WS. By convention, this equation assumes that the half life decreases with decreasing concentration (which supposedly more closely reflects the $\mathrm{C}$ turnover kinetics at our study sites).

\section{Statistical Analyses}

Statistical analysis was performed with the SYSTAT version 10.2 (SYSTAT 2002) by one-factorial analysis of variance using land cover (caatinga, trees, grass) as levels of one factor. The Tukey-Kramer test at the $95 \%$ confidence level was used for post hoc comparison to account for unequal sample sizes.

Differences between canopies and outside (grass) samples were determined by the dependent $t$ test for pairwise comparison. There were eight paired comparisons each for joazeiro, umbuzeiro, and prosopis vs. buffel grass and 24 for caatinga sites $1-3$ and the corresponding buffel grass (BC1$\mathrm{BC} 3)$.

\section{RESULTS AND DISCUSSION}

\section{Selective Clearing of Caatinga}

Conservation of Isolated Caatinga Trees. The $\delta^{13} \mathrm{C}$ values under the preserved umbuzeiro trees in the tree-pasture association were higher than those of the caatinga with WS of $-24.8 \%$ under the caatinga and $-23.7 \%$ ( $\pm 0.9 \%$ SE) under umbuzeiro and with LF of $-25.4 \%$ under caatinga and $-23.9 \%$ ( $\pm 1.5 \%$ SE) under umbuzeiro. The $\delta^{13} \mathrm{C}$ values in soils under joazeiro were only significantly greater in the LF with $-24.4 \%$ o $( \pm 1.0 \%$ SE; Table 1$)$. The $\mathrm{C}_{3}-\mathrm{C}$ concentration under caatinga was not significantly different from that under the preserved joazeiro and umbuzeiro trees in either the WS or the LF (Table 1).

Total $\mathrm{N}$ concentration under joazeiro, both in LF and WS was $50 \%$ higher than under caatinga. Umbuzeiro had about
$30 \%$ higher total $\mathrm{N}$ in the WS than caatinga; no significant differences were observed for the LF. The $\mathrm{P}_{\mathrm{o}}$ content in the WS was not different between the caatinga and the preserved joazeiro or umbuzeiro trees (Table 1 ). In the LF, the $P_{o}$ content under joazeiro was $40 \%$ higher than under caatinga. No differences were found between umbuzeiro and caatinga. Relative to the mean values in the caatinga, total soil $\mathrm{P}$ was $75 \%$ higher under the preserved joazeiro. An enrichment of $\mathrm{P}$ under the canopies of joazeiro was previously shown by Wick et al. (2000).

The higher $\delta^{13} \mathrm{C}$ under the preserved trees relative to the caatinga can be attributed to the input of $\mathrm{C}_{4}-\mathrm{C}$ by the buffel grass pasture under the tree canopies. The relative contribution of $\mathrm{C}_{4}-\mathrm{C}$ to the total soil $\mathrm{C}$ pool was more pronounced in the LF than in the WS, with values under joazeiro or umbuzeiro twice as high as caatinga values. The preserved trees maintained the $\mathrm{C}_{3}-\mathrm{C}$ levels found under caatinga. Total stocks of $\mathrm{C}, \mathrm{N}$, and $\mathrm{P}_{\mathrm{o}}$ were also maintained at or above the original caatinga level. The higher levels of $\mathrm{C}$ and nutrients under the preserved trees in the pasture compared with caatinga were also found under a single umbuzeiro and joazeiro in the natural caatinga (Table 1), which may indicate that the soils under joazeiro and umbuzeiro in the caatinga already had a higher $\mathrm{C}$ content and soil fertility than the surrounding caatinga. Both trees have a denser canopy than the average caatinga. Input of $\mathrm{C}_{3}-\mathrm{C}$, but also of $\mathrm{N}$ and $\mathrm{P}_{\mathrm{o}}$, with litter fall is, therefore, greater under joazeiro and umbuzeiro than under the average caatinga. Following the selective clearing, both trees maintained islands of higher soil fertility. Previous studies conducted in silvopastoral systems in semiarid northeastern Brazil demonstrated that preserving 30\% of the tree cover during the clearing of native caatinga increased forage production in comparison to areas where all trees were removed (Araújo Filho 1990). Following a shift from grassland to semideciduous thorn woodland, Liao et al. (2006a, 2006b) found increased $\mathrm{C}$ and $\mathrm{N}$ storage in soils. The increases in pool sizes were related to greater aboveground and belowground productivity of the woodlands relative to remnant grasslands, slower decomposition rates because of lower-quality substrates of woody plant inputs and better stabilization of macroaggregates and microaggregates within soil.

Replacement of Caatinga with Buffel Grass Pasture. The replacement of the caatinga $(\mathrm{C} 1-\mathrm{C} 3)$ with a buffel grass pasture $(\mathrm{BC} 1-\mathrm{BC} 3)$ has, after $14 \mathrm{yr}$, resulted in significantly greater $\delta^{13} \mathrm{C}$ values in both the WS and the LF. The $\delta^{13} \mathrm{C}$ signal in the WS increased by $\Delta+2.4 \%$ and in the LF soil by $\Delta+3.9 \%$ (Table 1). Caatinga contains a small proportion of plants with $\mathrm{C}_{4}$ as well as some with crassulacean metabolism. This mixed composition accounts for part of the $\mathrm{C}_{4}-\mathrm{C}$ content we calculated under caatinga. The $\mathrm{C}_{4}-\mathrm{C}$ newly sequestered by the buffel grass was found preferentially in the LF. The $\mathrm{C}_{4}-\mathrm{C}$ proportion in the WS was $13 \%$ under the caatinga and $32 \%$ in the pasture soil. In the LF, the relative proportion of $\mathrm{C}_{4}-\mathrm{C}$ to the total $\mathrm{C}$ pool was $8 \%$ under caatinga and $36 \%$ under pasture.

Total $\mathrm{C}$ in the pasture sites declined by $15 \%$ in the WS and by $50 \%$ in the LF (Table 1). The magnitude of loss of old $\mathrm{C}_{3}-\mathrm{C}$ from the caatinga was more pronounced in the LF than in the WS. Old $\mathrm{C}_{3}-\mathrm{C}$ in the WS decreased by $4.1 \mathrm{~g} \cdot \mathrm{kg}^{-1}$ and in the LF by $4.5 \mathrm{~g} \cdot \mathrm{kg}^{-1}$ (Table 1 ). 


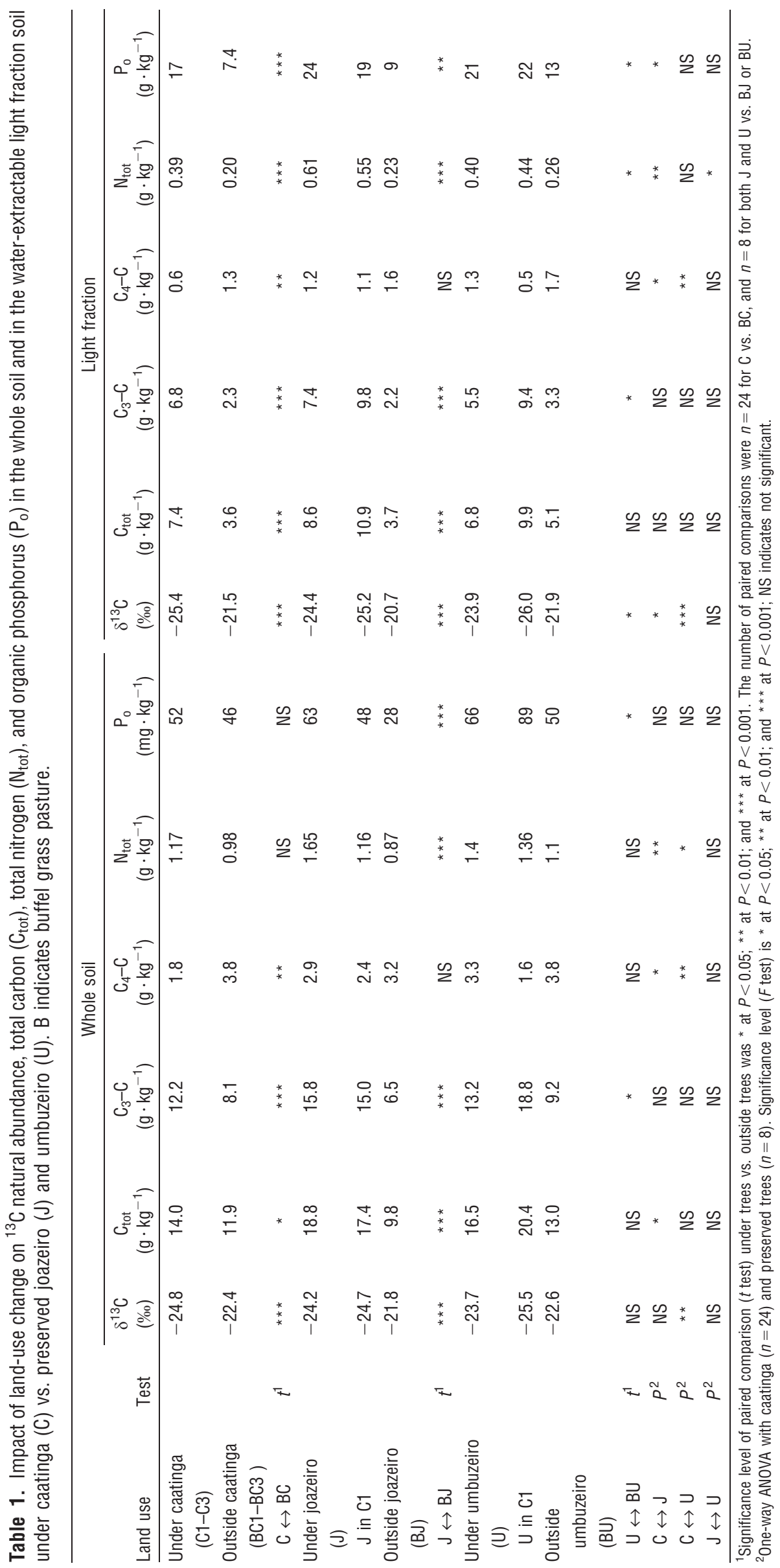


Total $\mathrm{N}$ and $\mathrm{P}_{\mathrm{o}}$ in the WS were not significantly different between the caatinga and the pasture sites, whereas the concentrations of total $\mathrm{N}$ and $\mathrm{P}_{\mathrm{o}}$ in the LF were reduced by $50 \%$ to $55 \%$ over $14 \mathrm{yr}$. The C: $\mathrm{N}$ ratios were between 12 and 13 in the WS and between 18 and 19 in the LF soil, reflecting less humification of SOM in the LF.

Under natural caatinga, the amount of $\mathrm{C}_{3}-\mathrm{C}$ stored in the $\mathrm{LF}$ accounted for half of the total $\mathrm{C}_{3}-\mathrm{C}$, whereas under pasture it accounted only for one-quarter of total $\mathrm{C}_{3}-\mathrm{C}$. Loss of $\mathrm{C}$ from the LF accounts for a large portion of $\mathrm{C}$ lost following the conversion of forest or grassland (Tiessen and Stewart 1983; Henderson et al. 2004) or vice versa, following a shift from grassland to woodland (Liao et al. 2006a). The decomposition losses of the old $\mathrm{C}_{3}-\mathrm{C}$ from the original caatinga level, after $14 \mathrm{yr}$, were twice as high from the LF soil $(-66 \%)$ as from the WS $(-34 \%)$. The calculated half lives of $\mathrm{C}$ were, accordingly, $19 \mathrm{yr}$ for the WS and $10 \mathrm{yr}$ for the LF soil. The loss of $\mathrm{C}_{3}-\mathrm{C}$ of $4.5 \mathrm{~g} \cdot \mathrm{kg}^{-1}$ from the LF was higher than that from WS, $4.1 \mathrm{~g} \cdot \mathrm{kg}^{-1}$, indicating that part of the LF material had broken down and become associated with a heavy fraction (HF), i.e., it does not represent a net loss from the soil. Other studies on $\mathrm{C}$ turnover in different fractions have also reported that, during decomposition, easily mineralizable $\mathrm{C}$ is partly transferred from the LF to the HF (Accoe et al. 2002). Our LF mineralization rates were similar to those reported for forestto-pasture conversion under humid subtropical conditions in Brazil (Cadisch et al. 1996), where about $50 \%$ of the original rainforest $\mathrm{C}_{3}-\mathrm{C}$ remained in the $53-100-\mu \mathrm{m}$ fraction of the 5$15-\mathrm{cm}$ layer, $18 \mathrm{yr}$ after forest conversion. The data indicate that SOM in the semiarid tropics can mineralize very rapidly. By comparison, our LF turnover rates were slower than those reported for forest-to-sugarcane (Saccharum officinarum L.) conversion in southeastern Brazil (Bonde et al. 1992), where the $\mathrm{C}$ turnover time in the sand-size fraction $(63-2000 \mu \mathrm{m})$ was $4 \mathrm{yr}$. The cultivation of the sugarcane field resulted in faster breakdown of the SOM, caused by increased aeration and the breakup of soil aggregates, than in the undisturbed pasture. Because the LF organic matter is less humified and generally free of mineral particles, this fraction decomposes more quickly than the WS (Hassink 1995; Six et al. 2002).

The $\mathrm{C}_{3}-\mathrm{C}$ in the labile $\mathrm{LF}$ was more rapidly replaced by $\mathrm{C}_{4}-\mathrm{C}$ than in the WS. The relative proportion of young $\mathrm{C}_{4}-\mathrm{C}$ to the total C pool was $19 \%$ in the WS and $28 \%$ in the LF. The input of new $\mathrm{C}_{4}-\mathrm{C}$ by the pasture grass, however, did not compensate for the loss of old $\mathrm{C}_{3}-\mathrm{C}$ that had occurred following caatinga clearing and pasture establishment.

Tree-Pasture Association: Under and Outside Tree Canopies. The differences in soil properties under the preserved trees compared with buffel grass pasture was evaluated by comparing values under the canopy with paired samples outside the canopies in the surrounding pasture.

The $\delta^{13} \mathrm{C}$ signal increased as the caatinga derived $\mathrm{C}_{3}-\mathrm{C}$ was replaced by pasture $\mathrm{C}_{4}-\mathrm{C}$ (Table 1 ). The $\delta^{13} \mathrm{C}$ values in the buffel grass outside the canopies of joazeiro were 2.4 units more positive in the WS and $3.7 \%$ more positive in the LF. These differences were slightly less in the pasture soils outside the canopies of umbuzeiro $(\Delta+1.1 \%)$ in the WS and $\Delta+2.0 \%$ in the LF (Table 1). The input of newly sequestered $\mathrm{C}_{4}-\mathrm{C}$ by the buffel grass under the canopies of joazeiro and umbuzeiro accounted for $15 \%-20 \%$ for both the WS and the LF soil. Outside the canopies of the trees $\mathrm{C}_{4}-\mathrm{C}$ of the pasture grass contributed between $30 \%$ and $40 \%$ to the total $\mathrm{C}$ pool for both the WS and the LF soil.

Total C was not different under and outside the canopies of umbuzeiro in either the WS or the LF soil. The loss of $\mathrm{C}_{3}-\mathrm{C}$ in the pasture outside the canopies of umbuzeiro amounted to $30 \%$ from the WS and to $40 \%$ from the LF soil (Table 1). Loss of total $\mathrm{N}$ in the soils outside the canopies of umbuzeiro was $35 \%$ from the LF soil. No significant differences were found for the WS. Loss of $\mathrm{P}_{\mathrm{o}}$ was $25 \%$ from the WS and $38 \%$ from the LF soil (Table 1). Total $\mathrm{C}, \mathrm{N}, \mathrm{C}_{3}-\mathrm{C}$, and $\mathrm{P}_{\mathrm{O}}$ in the pasture soils outside joazeiro trees were $50 \%-60 \%$ lower for WS and $60 \%-$ $70 \%$ for LF (Table 1). Outside the canopies of joazeiro the loss of total $\mathrm{C}$ and $\mathrm{C}_{3}-\mathrm{C}$ after $14 \mathrm{yr}$ was between $50 \%$ and $60 \%$ from the WS and between $60 \%$ and $70 \%$ from the LF (Table 1). About half of the total amount of $\mathrm{C}_{3}-\mathrm{C}$ lost in the cleared areas surrounding the joazeiro and umbuzeiro trees was due to a loss of $\mathrm{C}_{3}-\mathrm{C}$ from the $\mathrm{LF}$.

The ${ }^{13} \mathrm{C}$ data indicate that the elevated $\mathrm{C}$ contents under the trees relative to the pasture outside the tree canopies largely represent $\mathrm{C}_{3}$ levels already developed under caatinga. The joazeiro and umbuzeiro trees maintained between 1.4 and 2.4 times as much $\mathrm{C}_{3}-\mathrm{C}$ under their canopies in the WS and between 1.7 and 3.4 times as much in the LF than was found outside the canopies. The $\mathrm{C}_{3}-\mathrm{C}$ level under the canopies of joazeiro and umbuzeiro is similar to that of the caatinga indicating that the difference under and outside the tree canopies is due to a loss of $\mathrm{C}_{3}-\mathrm{C}$ from decomposition outside the canopy when the caatinga surrounding the trees was cleared and replaced by grass. The total amount of $\mathrm{C}_{3}-\mathrm{C}$ lost from the cleared areas surrounding the joazeiro trees was $9.3 \mathrm{~g} \cdot \mathrm{kg}^{-1}$ from the WS and $5.2 \mathrm{~g} \cdot \mathrm{kg}^{-1}$ from the LF. This corresponds to a $60 \%$ mineralization loss over $14 \mathrm{yr}$ from the WS and to $70 \%$ from the LF soil. The respective half life of $\mathrm{C}$ was $11 \mathrm{yr}$ for the WS and $9 \mathrm{yr}$ for the LF soil. By comparison, the total loss of $\mathrm{C}_{3}-\mathrm{C}$ outside the canopies of umbuzeiro amounted to $4.0 \mathrm{~g} \cdot \mathrm{kg}^{-1}(30 \%)$ from the WS and to $2.2 \mathrm{~g} \cdot \mathrm{kg}^{-1}(40 \%)$ from the LF. The corresponding half lives were $21 \mathrm{yr}$ for the WS and $16 \mathrm{yr}$ for the LF. Of the trees inherited from the native caatinga, joazeiro occurred almost exclusively in the lower landscape positions. Umbuzeiro occurred on both upper and lower positions. The faster mineralization of $\mathrm{C}$ in the lower landscape positions can be attributed to better soil moisture conditions, which stimulate microbial decomposition of SOM (Sommers et al. 1981). We found higher microbial activity under the joazeiro trees than under the umbuzeiro trees (Wick et al. 2000). SOM decomposition in grassland under semiarid temperate conditions is greatly influenced by water availability (Klein 1977), and greater access to the water table leads to higher productivity of the tree canopy (Belsky 1994; Schade et al. 2003). According to Menezes and Salcedo (1999) who worked in the same area, farmers prefer to establish agricultural fields in the lower landscape positions because of the higher soil moisture availability. In situ $\mathrm{N}$ mineralization rates were higher in the lower landscape positions than on higher parts of the landscape, even though total soil $\mathrm{N}$ was $55 \%-$ $246 \%$ higher in the latter (Menezes and Salcedo 1999). The $\mathrm{C}_{4}-\mathrm{C}$ contents were similar under and outside the tree canopies, i.e., little sequestration of new $\mathrm{C}$ had occurred in 
Table 2. Impact of land-use change on ${ }^{13} \mathrm{C}$ natural abundance, total carbon $\left(\mathrm{C}_{\text {tot }}\right)$, total nitrogen $\left(\mathrm{N}_{\text {tot }}\right)$, and organic phosphorous $\left(\mathrm{P}_{0}\right)$ in the whole soil and in the water-extractable light fraction soil under caatinga (C4), prosopis (P), and buffel grass (BP).

\begin{tabular}{|c|c|c|c|c|c|c|c|c|c|c|c|c|c|}
\hline \multirow[b]{2}{*}{ Land use } & \multirow[b]{2}{*}{ Test } & \multicolumn{6}{|c|}{ Whole soil } & \multicolumn{6}{|c|}{ Light fraction } \\
\hline & & $\begin{array}{l}\delta^{13} \mathrm{C} \\
(\% 0)\end{array}$ & $\begin{array}{c}\mathrm{C}_{\text {tot }} \\
\left(\mathrm{g} \cdot \mathrm{kg}^{-1}\right)\end{array}$ & $\begin{array}{c}\mathrm{C}_{3}-\mathrm{C} \\
\left(\mathrm{g} \cdot \mathrm{kg}^{-1}\right)\end{array}$ & $\begin{array}{c}\mathrm{C}_{4}-\mathrm{C} \\
\left(\mathrm{g} \cdot \mathrm{kg}^{-1}\right)\end{array}$ & $\begin{array}{c}\mathrm{N}_{\text {tot }} \\
\left(\mathrm{g} \cdot \mathrm{kg}^{-1}\right)\end{array}$ & $\begin{array}{c}\mathrm{P}_{\mathrm{o}} \\
\left(\mathrm{mg} \cdot \mathrm{kg}^{-1}\right)\end{array}$ & $\begin{array}{l}\delta^{13} \mathrm{C} \\
(\%)\end{array}$ & $\begin{array}{c}\mathrm{C}_{\text {tot }} \\
\left(\mathrm{g} \cdot \mathrm{kg}^{-1}\right)\end{array}$ & $\begin{array}{c}\mathrm{C}_{3}-\mathrm{C} \\
\left(\mathrm{g} \cdot \mathrm{kg}^{-1}\right)\end{array}$ & $\begin{array}{c}\mathrm{C}_{4}-\mathrm{C} \\
\left(\mathrm{g} \cdot \mathrm{kg}^{-1}\right)\end{array}$ & $\begin{array}{c}\mathrm{N}_{\text {tot }} \\
\left(\mathrm{g} \cdot \mathrm{kg}^{-1}\right)\end{array}$ & $\begin{array}{c}P_{0} \\
\left(\mathrm{mg} \cdot \mathrm{kg}^{-1}\right)\end{array}$ \\
\hline$\overline{\mathrm{C} 4}$ & & -24.2 & 16.5 & 13.7 & 2.8 & 1.5 & 113 & -24.8 & 6.4 & 5.6 & 0.8 & 0.37 & 24 \\
\hline$P$ & & -22.1 & 17.6 & 12.3 & 6.1 & 1.7 & 123 & -21.9 & 8.0 & 5.2 & 2.8 & 0.56 & 39 \\
\hline BP & & -21.3 & 17.5 & 10.5 & 6.9 & 1.8 & 120 & -19.8 & 6.3 & 3.3 & 3.0 & 0.40 & 26 \\
\hline $\mathrm{P} \leftrightarrow \mathrm{BP}$ & $t^{1}$ & NS & NS & NS & NS & NS & NS & NS & NS & NS & NS & NS & NS \\
\hline $\mathrm{C} 4 \leftrightarrow \mathrm{P} \leftrightarrow \mathrm{BP}$ & $\mathrm{LSD}^{2}$ & 0.8 & NS & 2.8 & 2.5 & NS & NS & 1.2 & NS & 1.2 & 1.0 & 0.12 & 8.8 \\
\hline
\end{tabular}

${ }^{1}$ Significance level of paired comparison ( $t$ test) of tree vs. buffel grass was ${ }^{*}$ at $P<0.05$; ${ }^{*}$ at $P<0.01$; and ${ }^{* \star *}$ at $P<0.001$. There were $n=8$ paired comparisons.

${ }^{2} \alpha=0.05$; one-way ANOVA caatinga, prosopis, and buffel grass $(n=8)$; NS indicates not significant.

the soil. Shading and nutrient inputs from the trees may have aided $\mathrm{C}_{4}-\mathrm{C}$ sequestration under the tree relative to the open grass land (Menezes et al. 2002; Tiessen et al. 2002). The preserved trees maintained islands of higher tree-derived soil C content, whereas the surrounding cleared areas had lost C.

Higher $\mathrm{P}$ availability under the tree canopies relative to the surrounding pasture sites is likely due to a greater activation of the P cycle (Wick et al. 2000) and the constantly mineralizing of $P_{o}$ inputs under the trees (Tiessen et al. 2002). A net import by the deep and extensive root system of joazeiro (Sampaio 1995) likely contributed further to nutrient accretion under the tree canopies relative to the surrounding pasture. Menezes et al. (2002) found that the loss of P from litter decomposition was lower under the canopies of joazeiro than in the surrounding pasture. The higher accumulation of $\mathrm{P}$ under the canopies of the shallow-rooting umbuzeiro trees (Epstein 1998) might be attributed to the input of fruits containing high concentrations of P. Umbuzeiro produces $60-300 \mathrm{~kg}$ of fruit per tree (Cavalcanti and Abilio de Queiroz 1992) with a P content of $140 \mathrm{mg} \cdot \mathrm{kg}^{-1}$ (Epstein 1998).

\section{Complete Replacement of Caatinga With Prosopis and Buffel Grass Plantation}

The elimination of the natural caatinga and replacement with a prosopis-buffel grass plantation resulted in a significant increase of the $\delta^{13} \mathrm{C}$ signal. In the WS, the ${ }^{13} \mathrm{C}$ value increased by $\Delta+2.0 \%$ under prosopis and by $\Delta+2.9 \%$ under pasture. The increase in the LF was $\Delta+2.9 \%$ under the trees and $\Delta+5.0 \%$ under pasture (Table 2).

Total $\mathrm{C}, \mathrm{N}$, and $\mathrm{P}_{\mathrm{o}}$ in the WS was not different between either the caatinga and the prosopis trees or the caatinga and the pasture soil (surrounding prosopis). In the LF, total $\mathrm{N}$ under prosopis increased by $50 \%$ and $\mathrm{P}_{\mathrm{o}}$ by $60 \%$ relative to the caatinga. No differences of total $\mathrm{C}, \mathrm{N}$, and $\mathrm{P}_{\mathrm{o}}$ were found between, under, or outside prosopis canopies (Table 2).

The $\mathrm{C}_{3}-\mathrm{C}$ inherited from the caatinga was maintained under the canopies of prosopis in both the WS and LF soil. Under pasture, however, the loss of the original caatinga $\mathrm{C}_{3}-\mathrm{C}$ after $14 \mathrm{yr}$ was $24 \%$ from the WS and $40 \%$ from the LF soil (Table 2).

The increase of $\delta^{13} \mathrm{C}$ under the canopies of prosopis is due to the input of $\mathrm{C}_{4}-\mathrm{C}$ by the buffel grass. The canopies of the prosopis trees are open and solar interception by the crowns is comparatively low so that buffel grass grows well underneath the trees (Menezes et al. 2002). Sequestration of SOM and N and $\mathrm{P}$ release from decomposing litter did not differ under or outside the trees, which is attributed to similar microclimatic conditions underneath the canopies and in the open buffel grass pasture (Menezes et al. 2002). There was no statistically significant difference of $\delta^{13} \mathrm{C}$, total $\mathrm{C}$ and $\mathrm{N}, \mathrm{C}_{3}$ and $\mathrm{C}_{4}-\mathrm{C}$, or $\mathrm{P}_{\mathrm{O}}$ under or outside the canopies of prosopis in either the WS or LF soil (Table 2).

Prosopis was planted after complete clearing of the caatinga. Although prosopis were much smaller trees at $12 \mathrm{yr}$ after planting than the mature umbuzeiro and joazeiro trees inherited from the caatinga, they also maintained $\mathrm{C}_{3}-\mathrm{C}$, total $\mathrm{N}$, and $\mathrm{P}_{\mathrm{o}}$ at or above the original caatinga. The young trees, therefore, maintained a resource island inherited from the caatinga. The establishment of buffel grass pasture following the clearing of the natural caatinga resulted in loss of caatinga $\mathrm{C}_{3}-\mathrm{C}$. The $\mathrm{C}$ mineralization in the pasture corresponds to a $24 \%$ loss over $14 \mathrm{yr}$ from the WS and to $40 \%$ loss from the LF. The respective half life of $\mathrm{C}$ was $28 \mathrm{yr}$ for the WS and $16 \mathrm{yr}$ for the LF and was similar to the values found in the other part of the ranch.

\section{IMPLICATIONS}

Land-use change from natural caatinga to silvopastoral ecosystems creates a patchy environment with small-scale enriched zones of soil organic matter and nutrients under the canopy of individual trees compared with the surrounding cleared pasture. This change in vegetation cover constitutes an important aspect of overall ecosystem functions for these semiarid environments. Our results demonstrate that both the preserved, mature trees of the caatinga and the younger trees planted after complete clearing of the caatinga prevented the SOM mineralization that occurred in the cleared pasture. The most critical loss of $\mathrm{C}, \mathrm{N}$, and $\mathrm{P}_{\mathrm{o}}$ occurred from the labile LF, indicating that the LF is more affected by land-use changes. The $\mathrm{SOM}$ in this tropical semiarid region is turning over and mineralizing at an extremely rapid rate, with half lives of $\mathrm{C}$ between 9 and $16 \mathrm{yr}$ for the LF and between 11 and $28 \mathrm{yr}$ for the WS. The elevated $\mathrm{C}_{3}-\mathrm{C}$ and the observed island of fertility under the canopies of the trees are inherited from the caatinga rather than built up by the trees. Islands of fertility have been reported in natural savannah or patchy vegetation systems where the patches have been formed over a long time. In the 
few cases where the persistence of such distinct vegetation patches has been reported, patches were still identifiable up to $30 \mathrm{yr}$ after clearing (Holland 1980; Tiedemann and Klemmedson 1986; Belsky and Canham 1994). Overall, these low-input silvopastoral management systems could hold promise as sustainable beef production systems through greater carbon sequestration and better retention of nutrients and organic matter.

\section{ACKNOWLEDGMENT}

We are grateful to Agropecuaria Jaçana for access to the sites and support in the field.

\section{LITERATURE CITED}

Accoe, F., P. Boeckx, O. Van Cleemput, G. Hofman, H. Hui Bin, and C. Guanxiong. 2002. Characterization of soil organic matter fractions from grassland and cultivated soils via $\mathrm{C}$ content and $\delta^{13} \mathrm{C}$ signature. Rapid Communications in Mass Spectrometry 16:2157-2164.

Araúso FILHo, J. A. 1990. Manipulação da vegetação lenhosa da caatinga para fins pastoris. Sao Paulo, Brazil: Embrapa Caprinos Circular Técnico 11. 18 p.

Babos, K., and L. J. C. Cumana. 1992. Xylotomical study of some Venezuelan tree species (Mimosaceae I-IV). Acta Botanica Hungarica 37:183-238.

Balesdent, J., AND A. Mariotti. 1996. Measurement of soil organic matter turnover using $13 \mathrm{C}$ natural abundance. In: T. W. Boutton and S. Yamasaki [EDS.]. Mass spectrometry of soils. New York, NY, USA: Marcel Dekker. p. 83-111.

Balesdent, J., A. Mariotti, and B. Guillet. 1987. Natural carbon-13 abundance as a tracer for studies of soil organic matter dynamics. Soil Biology and Biochemistry 19:25-30.

Barrios, E., R. Buresh, and J. I. Sprent. 1996. Nitrogen mineralization in density fractions of soil organic matter from maize and legume cropping systems. Soil Biology and Biochemistry 28:1459-1465.

Belsky, A. J. 1994. Influences of trees on savanna productivity: tests of shade, nutrients, and tree-grass competition. Ecology 75:922-932.

Belsky, A. J., and C. D. Canham. 1994. Forest gaps and isolated savanna trees. BioScience 44:77-84.

Bonde, T. A., B. T. Christensen, and C. C. Cerri. 1992. Dynamics of soil organic matter as reflected by natural ${ }^{13} \mathrm{C}$ abundance in particle size fractions of forested and cultivated oxisols. Soil Biology and Biochemistry 24:275-277.

Boone, R. D. 1994. Light fraction soil organic matter: origin and contribution to net nitrogen mineralization. Soil Biology and Biochemistry 26:1459-1468.

Cadisch, G., H. Imhof, S. Urquiaga, R. M. Boddey, and K. E. Gilleke. 1996. Carbon turnover $(\delta 13 \mathrm{C})$ and nitrogen mineralization potential of particulate light soil organic matter after rainforest clearing. Soil Biology and Biochemistry 28:1555-1567.

Cavalcanti, J., and M. Abilio de QuelRoz. 1992. Umbú gigante: informativo. São Joaquim, Brazil: Sociedade Brasileira de Fruticultura, Brazil.

Christensen, B. T. 1992. Physical fractionation of soil and organic matter in primary particle size and density separates. Advances in Soil Science 20:1-90.

Compton, J. E., And R. D. Boone. 2002. Soil nitrogen transformations and the role of light fraction organic matter in forest soils. Soil Biology and Biochemistry 34:933-943.

Curtin, D., F. M. McCallum, and P. H. Williams. 2003. Phosphorus in light fraction organic matter separated from soils receiving long-term applications of superphosphate. Biology and Fertility of Soils 37:280-287.

EITEN, G. 1992. Natural Brazilian vegetation types and their causes. Anais da Academia Brasileira de Ciencias 64(Suppl 1):35-65.

Epstein, L. 1998. A riqueza do umbuzeiro. Revista Bahia Agrícola 2:1-5.

Garcia-Miragaya, J., S. Flores, and N. Chacon. 1994. Soil chemical properties under individual evergreen and deciduous trees in a protected Venezuelan savanna. Acta Oecologica 15:477-484.
Gregorich, E. G., M. R. Carter, D. A. Angers, C. M. Monreal, and B. H. Ellert. 1994. Towards a minimum data set to assess soil organic matter quality in agricultural soils. Canadian Journal of Soil Science 74:367-385.

Gregorich, and H. H. Janzen. 1996. Storage of soil carbon in the light fraction and macroorganic matter. In: M. R. Carter and B. A. Stewart [EDS.]. Structure and organic matter storage in agricultural soils. Boca Raton, FL, USA: CRC Press. p. $167-190$.

HASSINK, J. 1995. Decomposition rate constants of size and density fractions of soil organic matter. Soil Science Society of America Journal 59:1631-1635.

HAYNES, R. J. 2000. Labile organic matter as an indicator or organic matter quality in arable and pastoral soils in New Zealand. Soil Biology and Biochemistry $32: 211-219$

Henderson, D. C., B. H. Ellert, and M. A. Naeth. 2004. Utility of ${ }^{13} \mathrm{C}$ for ecosystem carbon turnover estimation in grazed mixed grass prairie. Geoderma 119:219-231.

Holland, V. L. 1980. Effect of blue oak on rangeland forage production in central California. In: T. Plum [ED.]. Proceedings of the Symposium on Ecology, Management, and Utilization of California Oaks. Berkeley, CA, USA: USDA, Forestry Service, Pacific Southwest Forest and Range Experiment Station General Technical Report PSW-44. p. 314-318.

Janzen, H. H., C. A. Campbell, S. A. Brandt, G. P. Lafond, and L. Townley-Smith. 1992. Light-fraction organic matter in soils from long-term crop rotations. Soil Science Society of America Journal 56:1799-1806.

Jenkinson, D. S., P. B. S. Hart, J. H. Rayner, and L. C. Parry. 1987. Modeling the turnover of organic matter in long-term experiments at Rothamsted. INTECOL Bulletin 15:1-8

KLEIN, D. A. 1977. Seasonal carbon flow and decomposer parameter relationships in a semi-arid grassland soil. Ecology 58:184-1990.

LiaO, J. D., T. W. Boutton, AND J. D. Jastrow. 2006a. Storage and dynamics of carbon and nitrogen in soil physical fractions following woody plant invasion of grassland. Soil Biology and Biochemistry 38:3184-3196.

LIAO, J. D., T. W. BOUTTON, AND J. D. JASTROW. 2006b. Organic matter turnover in soil physical fractions following woody plant invasion of grassland: evidence from natural ${ }^{13} \mathrm{C}$ and ${ }^{15} \mathrm{~N}$. Soil Biology and Biochemistry 38:3197-3210.

Machado, I. C. S., L. M. Barros, and E. V. S. B. Sampalo. 1997. Phenology of caatinga species at Serra Talhada, PE, northeastern Brazil. Biotropica 29:57-68.

Manzoni, S., and P. Amilcare. 2007. A theoretical analysis of nonlinearities and feedbacks in soil carbon and nitrogen cycles. Soil Biology and Biochemistry 39:1542-1556.

Menezes, R. S. C., and I. H. Salcedo. 1999. Influence of tree species on the herbaceous understory and soil chemical characteristics in a silvopastoral system in semi-arid Northeastern Brazil. Revista Brasileira de Ciencias do Solo 23:817-826

Menezes, R. S. C., I. H. Salcedo, and E. T. Elliott. 2002. Microclimate and nutrient dynamics in a silvopastoral system of semiarid northeastern Brazil. Agroforestry Systems 56:27-28.

Noel, D. 1995. Ziziphus: jujube family species, distribution, exploitation. Yearbook West Australian Nut and Tree Crops Association 19:14-20.

Paul, E. A. 1984. Dynamics of organic matter in soils. Plant and Soil 76:275-285.

RHOADES, C. C. 1997. Single-tree influences on soil properties in agroforestry: lessons from natural forest and savanna ecosystems. Agroforestry Systems 35:71-94.

Sampalo, E. V. S. B. 1995. Overview of the Brazilian caatinga. In: S. H. Bullock, H. A. Mooney, and E. Medina [EDS.]. Seasonally dry tropical forests. Cambridge, United Kingdom: Cambridge University Press. p. 35-63.

Saunders, W. M. H., and E. G. Williams. 1955. Observations on the determination of total organic phosphorus in soils. Journal of Soil Science 6:254267.

Schade, J. D., S. Collins, R. Sponseller, and A. Stiles. 2003. The influence of mesquite on understory vegetation: effects of landscape position. Journal of Vegetation Science 14:743-750.

Shang, C., and H. Tiessen. 1998. Organic matter stabilization in two semiarid tropical soils: size, density, and magnetic separations. Soil Science Society of America Journal 62:1247-1257. 
Shang, C., And H. Tiessen. 2001. Carbon turnover and carbon-13 natural abundance in organo-mineral fractions of a tropical dry forest soil under cultivation. Soil Science Society of America Journal 64:2149-2155.

Six, J., C. Feller, K. Denef, S. M. Ogle, J. C. de Moraes Sa, and A. Albrecht. 2002. Soil organic matter, biota and aggregation in temperate and tropical soilseffects of no-tillage. Agronomie 22:755-775.

Six, J., and J. D. Jastrow. 2002. Soil organic matter turnover. In: R. Lal [ED.]. Encyclopedia of soil science. New York, NY, USA: Marcel Dekker. p. 936-942.

Sommers, L. E., C. M. Gilmour, R. E. Wildung, and S. M. BeCK. 1981. The effect of water potential on decomposition processes in soils. In:J. F. Parr, W. R. Gardner, and L. F. Elliot [EDS.]. Water potential relations in soil microbiology. Madison, WI, USA: Soil Science Society of America Special Publication 9. p. 97-117.

SYSTAT FOR WIndows [COMPUTER PROGRAM]. 2002. Version 10.2. Evanston, IL, USA: Systat, Inc.

ThomAs, R. L. 1967. Comparison of conventional and automated procedures for nitrogen, phosphorus, and potassium analysis of plant material using a single digestion. Agronomy Journal 59:240-243.

Tiedemann, A. R., and J. O. Klemmedson. 1986. Long-term effects of mesquite removal on soil characteristics, I: nutrients and bulk density. Soil Science Society of America Journal 50:472-475.

Tiessen, H., E. Cuevas, and P. Chacon. 1994. The role of soil organic matter in sustaining soil fertility. Nature $371: 783-785$.

Tiessen, H., R. S. C. Menezes, I. H. Salcedo, and B. Wick. 2002. Tree effects, soil fertility and organic matter turnover in a silvo-pastoral system in semiarid NE Brazil. Plant and Soil 252:195-205.
Tiessen, H., And J. O. Moir. 1993. Characterization of available phosphorus by sequential extraction. In: M. R. Carter and the Canadian Society of Soil Science [EDS.]. 1993. Soil sampling and methods of analysis. Ann Arbor, MI, USA: Lewis Publishers. p. 75-86.

Tiessen, H., and J. W. B. Stewart. 1983. Particle-size fractions and their use in studies of soil organic matter, II: cultivation effects on organic matter composition in size fractions. Soil Science Society of America Journal 47:509-514.

Trumbore, S. E. 1993. Comparison of carbon dynamics in tropical and temperate soils using radiocarbon measurements. Global Biogeochemical Cycles 7:275-290.

Weltzin, J. F., And M. B. Coughenour. 1990. Savanna tree influence on understory vegetation and soil nutrients in northwestern Kenya. Journal of Vegetation Science 1:325-334.

Whalen, J. K., P. J. Bottomley, and D. D. Myrold. 2000. Carbon and nitrogen mineralization from light- and heavy-fraction additions to soil. Soil Biology and Biochemistry 32:1345-1352.

Wick, B., H. Tiessen, and R. S. C. Menezes. 2000. Land quality changes following the conversion of natural vegetation into silvo-pastoral systems in semiarid NE Brazil. Plant and Soil 222:59-70.

Young, A. 1997. Effects of trees on soils. In: A. Young [ED.]. Agroforestry for soil management, 2nd ed. Wallingford, United Kingdom: $C A B$ International. p. 23-52, 111-136.

ZINKE, P. J. 1962. The pattern of influence of individual forest trees on soil properties. Ecology 43:130-133. 